Dr inż. Anna Szafarczyk,

AGH Akademia Górniczo-Hutnicza

Anna.Szafarczyk@agh.edu.pl

\title{
IDENTYFIKACJA OBSZARÓW OSUWISKOWYCH W REJONIE JEZIORA MUCHARSKIEGO W ASPEKCIE BEZPIECZEŃSTWA ZAPORY ŚWINNA PORĘBA
}

\begin{abstract}
Streszczenie
Wskutek uruchomienia zbiornika retencyjnego i zapory Świnna Poręba na rzece Skawie nastąpiła zmiana poziomu zwierciadła wody płynącej o blisko 30 metrów. W momencie ustalenia tak zwanego normalnego poziomu piętrzenia wody (305.5 m n.p.m.), zbocza doliny zostały całkowicie lub częściowo zalane. Jest to sytuacja skrajnie niekorzystna, gdyż woda jest jednym z podstawowych czynników aktywizujących ruchy masowe. Wykonane badania geologiczne na zboczach zbiornika pozwoliły na wytypowanie rejonów zagrożonych i ich późniejsze zabezpieczenie co stanowiło element zarządzania ryzykiem w trosce o zapewnienie bezpieczeństwa zapory.

słowa kluczowe: zapora, zagrożenie osuwiskowe
\end{abstract}

\section{IDENTIFICATION OF LANDSLIDES IN THE AREA OF THE MUCHARSKIE LAKE IN THE ASPECT OF THE ŚWINNA PORĘBA RESERVOIR SAFETY}

\begin{abstract}
Summary
As a result of the launch of the Świnna Poręba reservoir and dam on the Skawa river, there has been a change in the level of the water table flowing by nearly 30 meters. At the time when the so-called normal level of water damming ( $305.5 \mathrm{~m}$ above sea level) was established, the valley slopes were completely or partially flooded. This is an extremely unfavorable situation, because water is one of the basic factors stimulating mass movements. The geological surveys carried out on the slopes of the reservoir allowed for the identification of endangered areas and their subsequent securing, which was an element of risk management in the interest of ensuring the safety of the dam.
\end{abstract}

keywords: dam, landslide hazard

\section{Wprowadzenie}

Kiedy w cieku następują duże wahania stanów wód, okresowo mogą one opuszczać koryto, szeroko rozlewać się i kształtować dolinę rzeki [16]. Działalność niszcząca wód polega na pogłębieniu i poszerzeniu doliny w procesie zwanym erozją. Działalność erozyjna ma zróżnicowanie natężenie w poszczególnych odcinkach biegu rzeki (Rys. 1.1). 


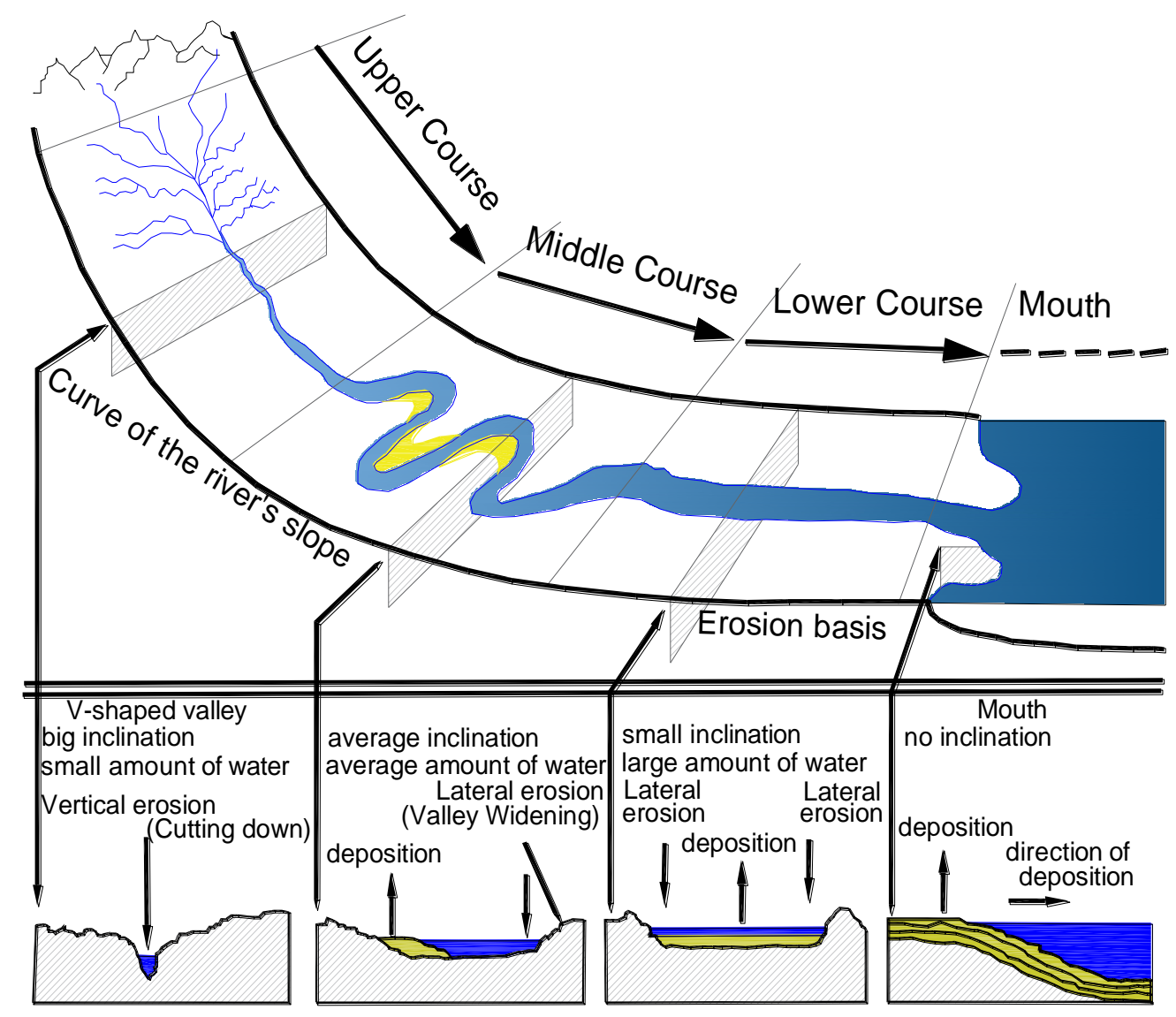

Rys. 1.1 Działalność wody płynącej

Niszczenie brzegów przebiega $\mathrm{w}$ różnym tempie i zależy od siły wody, ilości transportowanego materiału, nachylenia terenu, odporności skał budujących brzegi. Rzeka zaczyna płynąć coraz bardziej krętym korytem, wydłużając bieg rzeki poprzez zakola, zwane meandrami. Najbardziej atakowane przez erozję są wybrzuszenia meandrów stale powiększające się, zaś po stronie przeciwnej, gdzie woda płynie wolniej, następuje osadzanie transportowanego materiału.

\section{Działalność człowieka jako czynnik morfogenetyczny}

Rzeźba terenu kształtowana może być przez człowieka w sposób zamierzony jak i niezamierzony. Intensywność przemian rzeźby może się zwiększać w zależności od rodzaju i natężenia działalności człowieka oraz jej zróżnicowania w czasie i przestrzeni [12]. W opracowaniach dotyczących przemian rzeźby pod wpływem działalności człowieka zwracano głównie uwagę na : wpływ użytkowania terenu na tempo procesów morfogenetycznych w zlewniach [7], [10], [6], [8], [12], [14], [15], [18], [1]. Jedną z form działalności człowieka mającą pośrednio wpływ na kształtowanie rzeźby terenu jest regulacja biegu rzek, w szczególności poprzez budowę sztucznych zbiorników wodnych istotnych dla ochrony przeciwpowodziowej. Dotychczas w skali obszaru dorzecza Wisły zlokalizowano 33 zbiorniki (o pojemności powyżej $3 \mathrm{mln}^{3}$ ) [21].

\section{Zbiornik Świnna Poręba}

Ostatnią większą budowlą hydrotechniczną jest zbiornik Świnna Poręba o pojemności 160 $\mathrm{mln} \mathrm{m}^{3}$, wybudowany na rzece Skawie $\mathrm{w} \mathrm{km} \mathrm{26+600} \mathrm{biegu} \mathrm{rzeki.} \mathrm{Zbiornik} \mathrm{położony} \mathrm{jest}$ w województwie małopolskim $\mathrm{w}$ powiatach wadowickim i suskim, na terenach gmin Mucharz, Stryszów i Zembrzyce. Przekrój piętrzenia- zapora ( o wysokości 54 metry 
i długości 604 metry), znajduje się w miejscowości Świnna Poręba, w odległości ok. 6 km na południe od Wadowic. Zbiornik posiada bardzo urozmaiconą linię brzegową i rozciąga się od miejscowości Świnna Poręba do miejscowości Zembrzyce na długości ok.11 km. [20].

$\mathrm{Na}$ zbiorniku wodnym Świnna Poręba znajdują się 3 automatyczne posterunki wodowskazowe do kontroli bilansu wodnego zbiornika. Rzędna minimalnego, normalnego i maksymalnego poziomu piętrzenia wynoszą odpowiednio: $288,5 \mathrm{~m} \mathrm{npm}, 309,5 \mathrm{~m}$ npm i $312,0 \mathrm{~m}$ npm w układzie wysokościowym Kronsztadt. W wyniku uruchomienia zapory i napełniania zbiornika zajmuje on powierzchnię minimalną wynoszącą 224 hektary i maksymalną wynoszącą 1035 hektarów.

Przy napełnieniu zbiornika sytuacja hydrogeologiczna zboczy budujących czasze zbiornika ulega drastycznej zmianie. Sytuacja ta wydaje się być ustabilizowana w momencie osiągnięcia docelowego poziomu piętrzenia wody. Stan ten jest jednak pozornie stabilny i bezpieczny, gdyż pierwsze i kolejne wezbrania następujące po osiągnięciu docelowego poziomu piętrzenia wody stanowić mogą również zagrożenie dla stabilności zboczy. W zmienionym stanie -dotychczas spoczywające na zboczach grunty i rumosz skalny staja się gruntami zawodnionymi, co diametralnie zmienia ich własności fizyko-mechaniczne i powodować może w konsekwencji nawet utratę stateczności tego zbocza. Ze wszech miar sytuacja taka jest niepożądana, stąd też działania służb geologicznych mają na celu zinwentaryzowanie terenów osuwiskowych w rejonie czaszy zbiornika, ich zbadanie i określenie konieczności ich zabezpieczenia.

\section{Ruchy masowe}

Osuwiska mogą być spowodowane przez ciek lub fale podcinające podnóże stoku, co występuje w szczególności w przypadku podnoszenia się zwierciadła wody w rzece. W przypadku budowy zapory wodnej i jej rozruchu w naturalny sposób następuje napełnianie utworzonego zbiornika wodą, a dynamika tego procesu związana jest z dynamiką i ilością występujących opadów atmosferycznych. Podczas napełniana zbiornika następuje sukcesywne podniesienie się zwierciadła wody (poziom piętrzenia), co wpływa pośrednio na zmianie poziomu wód gruntowych rejestrowana w piezometrach. Dodatkowo, na skutek podniesienia się zwierciadła wody w rzece, dotychczasowa morfologia dna koryta rzecznego ulega zmianie zyskując dodatkową powierzchnię zajętą przez wodę płynącą. Ma to fundamentalne znaczenie dla kształtowania się dalszych procesów transportu, akumulacji i denudacji. Zintensyfikowanie tych procesów może w dalszej konsekwencji prowadzić do naruszenia istniejącego stanu równowagi zboczy budujących dolinę i potencjalnie do uaktywnienia się procesów osuwiskowych.

Przykłady katastrof zapór wodnych na świecie (Tab. 3.1) wskazują na konieczność prowadzenia gruntownych badań geologicznych rejonu posadowienia projektowanej zapory, jak również zboczy doliny zajętej pod projektowany zbiornik wodny. Zarządzanie ryzykiem powinno być również kontynuowane nieprzerwanie w czasie eksploatacji zbiornika.

Tab. 3.1 Zestawienie wybranych katastrof zapór wodnych.

\begin{tabular}{|l|l|l|l|}
\hline Nazwa & $\begin{array}{l}\text { Data katastrofy } \\
\text { Lokalizacja } \\
\text { rzeka/państwo }\end{array}$ & Przyczyna katastrofy & $\begin{array}{l}\text { Oszacowane szkody / ilość } \\
\text { ofiar }\end{array}$ \\
\hline Malpasset & $\begin{array}{l}\text { 2 grudnia 1959 } \\
\text { Reyran/Francja }\end{array}$ & $\begin{array}{l}\text { niewystarczające } \\
\text { badania geologiczne na } \\
\text { etapie projektowania i } \\
\text { budowy zapory }\end{array}$ & $\begin{array}{l}\text { 68mld dolarów/ według } \\
\text { różnych źródeł od 361 do } \\
510 \text { ofiar }\end{array}$ \\
\hline Vaiont & $\begin{array}{l}9 \text { października } \\
1963\end{array}$ & $\begin{array}{l}\text { zbagatelizowane } \\
\text { zostały n niektóre }\end{array}$ & 1917 ofiar \\
\hline
\end{tabular}




\begin{tabular}{|l|l|l|ll|}
\hline & Vaiont/Włochy & $\begin{array}{l}\text { obserwacje geologiczne } \\
\text { na zboczach zbiornika, }\end{array}$ & \\
\hline Austin & $\begin{array}{l}30 \quad \text { września } \\
1911 \text { Freeman } \\
\text { Run/USA }\end{array}$ & $\begin{array}{l}\text { wygięcie i spękanie } \\
\text { zapory na skutek } \\
\text { nagłego jej napełnienia } \\
\text { po odwilży }\end{array}$ & $\begin{array}{l}\text { ówczesnych 10 } \\
\text { dolarów/78 osób }\end{array}$ & mln \\
\hline Morvi & $\begin{array}{l}11 \quad \text { sierpnia } \\
\text { Manchhu/Indie }\end{array}$ & $\begin{array}{l}\text { wyniku wysadzenia } \\
\text { zapory ściana wody } \\
\text { runęła potężna siłą i } \\
\text { zniszczyła miasto }\end{array}$ & $\begin{array}{l}\text { według różnych źródeł od } \\
1500 \text { do 12000 osób }\end{array}$ \\
\hline $\begin{array}{l}\text { Tama } \\
\text { Banqiao } \\
\text { oraz tama } \\
\text { Shimantan }\end{array}$ & $\begin{array}{l}1975 \\
\text { prowincja }\end{array}$ & $\begin{array}{l}\text { Wenan/Chiny } \\
\text { towarzyszącej powodzi } \\
\text { tajfunowi Nina }\end{array}$ & $\begin{array}{l}\text { 26000 ludzi zginęło podczas } \\
\text { powodzi po zerwaniu tamy } \\
\text { oraz dodatkowo umarło } \\
145000 \text { w wyniku następnie } \\
\text { epidemii oraz klęski głodu }\end{array}$ \\
\hline
\end{tabular}

\section{Czynniki wpływające na występowanie osuwisk}

W ocenie podatności osuwiskowej gromadzi się szereg danych, dotyczących budowy geologicznej, ukształtowania terenu, jego użytkowania, bliskości obiektów mających niekorzystny wpływ na stabilność stoku, a następnie na ich podstawie dokonuje się analizy, w wyniku której tworzona jest mapa zagrożenia osuwiskowego. Mapa taka może być również wykreślona $\mathrm{w}$ oparciu o dodatkowo wykonane zdjęcia lotnicze i satelitarne, jak również badania terenowe w tym pomiary geodezyjne. Podstawowe parametry wykorzystywane podczas tworzenia map zagrożenia osuwiskowego to: litologia, zagospodarowanie terenu, kąt nachylenia stoku, azymut maksymalnego nachylenia, wysokość n.p.m., odległość od rzeki, odległość od drogi, odległośc od uskoków, typ gleby, współczynnik zdolności transportowania osadu (LS), indeks siły spływu (SPI), opady deszczu.

\section{Litologia}

Sprzyjająca litologia i układ warstw (czyli generalnie naprzemianległe występowanie skał luźnych i zwięzłych lub warstw/gruntów spoistych i niespoistych) - jest bardzo istotnym elementem budowy geologicznej, od którego w dużej mierze zależy powstanie i rozwój ruchów masowych. Do rozwoju procesów osuwiskowych dochodzi najczęściej na pograniczu skał o różnych właściwościach fizycznych i o różnej przepuszczalności. Za układ najbardziej sprzyjający rozwojowi ruchów masowych należy uznać taki, w którym w obrębie zbocza/stoku odsłaniają się warstwy o różnej litologii i różnej przepuszczalności, nachylone zgodnie z kierunkiem nachylenia powierzchni terenu. We fliszu karpackim ruchy osuwiskowe powstają najczęściej na kontakcie warstw piaskowców i iłołupków. Zjawisko to jest uwarunkowane przez wiele czynników. Między innymi są to: sprzyjająca powstawaniu osuwisk budowa geologiczna, geometria zbocza, wielkość i intensywność opadów atmosferycznych i związane z tym wahania poziomu wód podziemnych, wpływ działalności gospodarczo - przemysłowej człowieka, zmiana szaty roślinnej itp. Ważnym czynnikiem generującym powstawanie osuwisk jest również zmiana tekstury gruntów takich jak iły i iłołupki [17], [19].

W omawianym przypadku iły i iłołupki wchodzące w skład profilu litologicznego fliszu karpackiego zaliczają się do gruntów ekspansywnych. Podlegają one pęcznieniu, które wpływa między innymi na osłabienie ich parametrów wytrzymałościowych. Osłabienie gruntów poprzez wzrost ich wilgotności na skutek pęcznienia może spowodować powstawanie osuwisk. 


\section{Zagospodarowanie terenu}

Bezpośredni wpływ na powstanie osuwiska może mieć podcięcie zbocza wykopami czy przeciążenie zbocza nasypami, lub obiektami budowlanymi.

W omawianym przypadku rejonu zapory Świnna Poręba zbocze podcinane jest przez wodę gromadzoną $\mathrm{w}$ zbiorniku retencyjnym.

\section{Kąt nachylenia stoku}

Określenie przedziału wartości nachyleń (od-do) przy których dochodzi najczęściej do rozwoju ruchów masowych na stoku jest zagadnieniem bardzo trudnym i dotychczas nie do końca poznanym i zbadanym. Upraszczając problem można powiedzieć, że zależy to od 3 podstawowych komponentów:

- rodzaju gruntów w obrębie których rozwinięty jest stok (decydujące znaczenie ma tutaj kąt tarcia wewnętrznego);

- wysokości względnej zbocza/stoku;

- rodzaju przemieszczenia (spływ, zsuw, spełzywanie, obryw).

Zgodnie $\mathrm{z}$ przyjętymi uproszczonymi założeniami funkcjonują różnego rodzaju klasyfikacje nachyleń opracowane dla gruntów niespoistych (piasków) i spoistych (glin i iłów). Generalnie wynika z nich, że na zboczach/stokach zbudowanych z utworów ilastych osuwiska praktycznie nie występują przy nachyleniu powierzchni poniżej $6^{\circ} \div 8^{\circ}$, a w utworach piaszczysto-pylastych poniżej $22^{\circ}$. W warunkach rzeczywistych pojawiają się niejednokrotnie dodatkowe elementy (np. obecność wycieków, wysięków na zboczu, obecność lub brak pokrywy roślinnej), które powodują, że przemieszczenie gruntu na stoku może zachodzić przy jego mniejszych nachyleniach.

\section{Odległość od rzeki}

Płytko występujący poziom wód gruntowych lub obecność źródeł/wysięków/wycieków na zboczach dolin lub stokach wzgórz i gór wskazuje pośrednio na predyspozycję obszaru do rozwoju ruchów masowych. Stały dopływ wód przy korzystnej budowie geologicznej (wypływ w obrębie warstw przepuszczalnych poniżej lub powyżej których występują warstwy słabo przepuszczalne - np. gliny, łupki, iłołupki, iłowce lub warstwy bardzo słabo przepuszczalne - iły) może warunkować przemieszczenie gruntów, które nastąpi najprawdopodobniej wzdłuż granicy geologicznej (nawodniona warstwa przepuszczalna sucha warstwa słabo przepuszczalna). Obecność wód w strefie przypowierzchniowej jest głównym czynnikiem sprawczym przemieszczenia gruntu i przyspieszającym rozwój ruchów masowych.

\section{Ilość opadów}

$\mathrm{Na}$ podstawie pracy Święchowicz [14] największa potencjalna transformacja stoków możliwa jest w lecie. Wtedy okres występowania deszczów potencjalnie erozyjnych jest najdłuższy. Na podstawie tylko częstości występowania opadów można wnosić, że dynamika procesów erozyjnych wiosną i jesienią jest podobna. Najdłuższe okresy stabilności stoków przypadają na zimę i jesień, najkrótsze zaś występują latem. Reżim hydrologiczny rzek Beskidu Niskiego jest typowym niewyrównanym reżimem górskim, z zasilaniem deszczowogruntowo-śnieżnym i wezbraniami w okresie wiosennym, letnim i wczesnozimowym [3], [13]. Dominujące są coroczne, regularnie występujące wezbrania wiosenne. Drugorzędne wezbrania występują latem i występują podczas opadów rozlewnych, a także wczesnozimowe związane z tajaniem pokrywy śnieżnej i opadem deszczu. Zmienność stanów wody na badanym obszarze jest typowa dla rzek górskich. 


\section{Identyfikacja osuwisk w rejonie zapory Świnna Poręba}

$\mathrm{Na}$ podstawie wykonanych badan geologicznych scharakteryzowanych $\mathrm{w}$ tabeli 6.1 w rejonie czaszy zbiornika zinwentaryzowano 26 osuwisk, których lokalizację przedstawiono na rysunku 6.1.

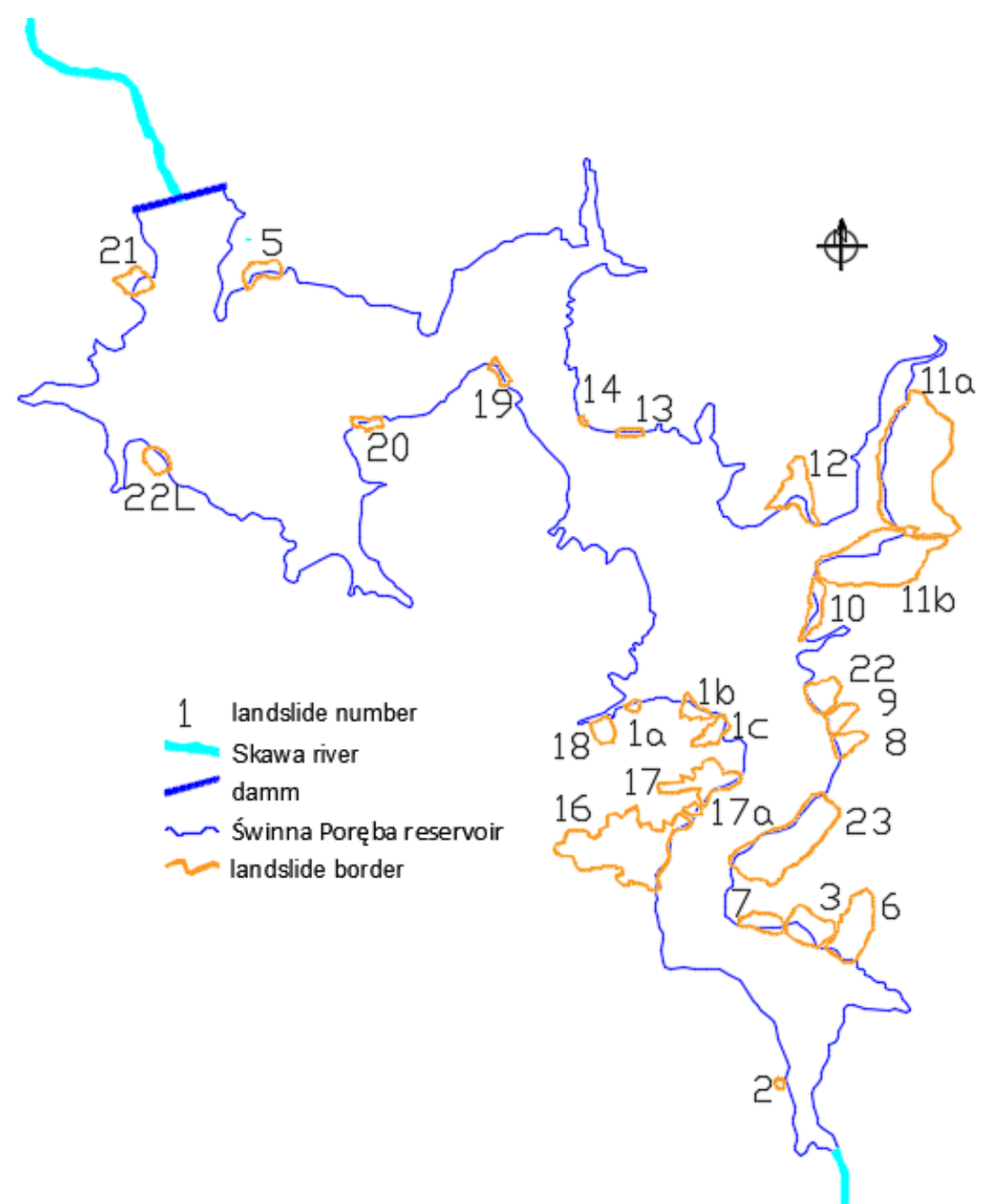

Rys. 6.1 Lokalizacja osuwisk w rejonie czaszy zbiornika Świnna Poręba

Tab. 6.1 Zestawienie badań wykonanych na terenie osuwisk zlokalizowanych w rejonie czaszy zbiornika Świnna Poręba

\begin{tabular}{|l|l|l|l|l|}
\hline $\begin{array}{l}\text { Oznaczenie } \\
\text { osuwiska }\end{array}$ & $\begin{array}{l}\text { Otwory (otwory badawcze, inklinometry, } \\
\text { piezometry) }\end{array}$ & $\begin{array}{l}\text { Przekroje } \\
\text { geologiczno } \\
-\end{array}$ & $\begin{array}{l}\text { Profile } \\
\text { sejsmiczne } \\
\text { Profile } \\
\text { geoelektryczne }\end{array}$ & $\begin{array}{l}\text { Archiwalne } \\
\text { wyrobisk } \\
\text { górnicze } \\
\text { (szybiki) }\end{array}$ \\
\hline 21 & OB- $1 / 21$, OB-3/21, OB-4/21 & VIII-VIII' & $21-1,21-2$ & \\
\hline $22 \mathrm{~L}$ & OB-1/22L, OB-2/22L, OB-3/22L & IX-IX' & $22 \mathrm{~L}-1,22 \mathrm{~L}-2$ & \\
\hline 20 & OB-1/20 & X-X' & & Sz203, Sz204 \\
\hline 19 & \multicolumn{2}{|l|}{ XI-XI' } & & Sz211 \\
\hline 18 & OB-1/18, OB-2/18 & XII-XII' & & \\
\hline $1 \mathrm{a}$ & OTW-1, OTW-2, OTW-3 & I-I' & & \\
\hline $1 \mathrm{~b}$ & OB-1/18 & XIII-XIII' & & \\
\hline $1 \mathrm{c}$ & $\begin{array}{l}\text { OTW-4, OTW-5, OTW-6, OTW-7, OTW-8, } \\
\text { OTW- } 9 \text { II-II' }\end{array}$ & & \\
\hline 17 & $\begin{array}{l}\text { OTW-10, OTW-11, OTW-12, OTW-13, } \\
\text { OTW-14, OTW-15, OTW-16, OTW-17, } \\
\text { OTW-18, OTW-19, OTW-20 }\end{array}$ & III-II' & & \\
\hline
\end{tabular}




\begin{tabular}{|c|c|c|c|c|}
\hline $17 \mathrm{a}$ & & & & \\
\hline 16 & $\begin{array}{llll}\text { OTW-21, } & \text { OTW-22, } & \text { OTW-23, } & \text { OTW-24, } \\
\text { OTW-25, } & \text { OTW-26, } & \text { OTW-27, } & \text { OTW-28, } \\
\text { OTW-29, OTW-30 } & & \end{array}$ & IV-IV' & & \\
\hline 2 & OB-1/2 & I-I' & & \\
\hline 6 & OB-1/6, OB-2/6, OB-3/6, OB-4/6 & I-I' & & $\begin{array}{l}\text { Sz872, Sz873 } \\
\text { Sz874 }\end{array}$ \\
\hline 3 & OB- $1 / 3$, OB-2/3, OB-3/3 & II-II' & & \\
\hline 7 & OB-1/7, OB-2/7 & II-III' & & \\
\hline 23 & $\begin{array}{l}\text { OB-1/23, OB-2/23, OB-3/23, OB-4/23, OB- } \\
5 / 23, \text { OB-6/23, OB-7/23, OB-8/23, OB-9/23, } \\
\text { OB-10/23 }\end{array}$ & $\begin{array}{l}\text { II-II' } \\
\text { II-III' }\end{array}$ & $\begin{array}{l}23-1,23-2 \\
23-3,23-4\end{array}$ & Sz840 \\
\hline 8 & OB-1/8, OB-2/8, OB-3/8 & IV-IV' & $8-1$ & \\
\hline 9 & OB-1/9 & $\mathrm{V}-\mathrm{V}^{\prime}$ & $9-1$ & Sz827, Sz828 \\
\hline 22 & OB-1/22, OB-2/22, OB-4/22 & VI-VI' & $\begin{array}{l}22-(1-2), 22-3, \\
22-4\end{array}$ & Sz824, Sz823 \\
\hline 10 & $\begin{array}{l}\text { OB-1/10, OB-2/10, OB-3/10 } \\
\text { OB-4/10, OB-5/10, OB-6/10 }\end{array}$ & VII-VII' & $\begin{array}{l}10-1,10-2 \\
10-3\end{array}$ & Sz1092 \\
\hline $11 \mathrm{~b}$ & $\begin{array}{l}\text { OB-1/11B, OB-2/11B, OB-3/11B } \\
\text { OB-4/11B, OB-5/11B, OB-6/11B } \\
\text { OB-7/11B, OB-8/11B, OB-9/11B } \\
\text { OB-10/11B, OB-11/11B, } \\
\text { OB-12/11B, OB-13/11B }\end{array}$ & $\begin{array}{l}\text { VII-VII' } \\
\text { IX-IX' }\end{array}$ & $\begin{array}{l}11 \mathrm{~b}-1,11 \mathrm{~b}-2, \\
11 \mathrm{~b}-3,11 \mathrm{~b}-4, \\
11 \mathrm{~b}-5 \\
11 \mathrm{~b}-(6-7) \\
11 \mathrm{~b}-9\end{array}$ & Sz1086 \\
\hline $11 \mathrm{a}$ & $\begin{array}{l}\text { OB-1/11A, OB-2/11A, OB-3/11A, OB-4/11A, } \\
\text { OB-5/11A, OB-6/11A } \\
\text { OB-7/11A, OB-8/11A, OB-9/11A, OB- } \\
\text { 10/11A, OB-11/11A, } \\
\text { OB-12/11A, OB-13/11A, } \\
\text { OB-14/11A }\end{array}$ & $\begin{array}{l}\mathrm{X}-\mathrm{X}^{\prime} \\
\text { XI-XI' }\end{array}$ & $\begin{array}{l}11 a-1,11 a-2, \\
11 a-3,11 a-4 \\
11 a-5\end{array}$ & \\
\hline 12 & $\begin{array}{l}\text { OB-1/12, OB-2/12, OB-3/12, } \\
\text { OB-4/12, OB-5/12 }\end{array}$ & IV-IV' & $\begin{array}{l}12-1,12-2, \\
12-3\end{array}$ & RSz163 \\
\hline 13 & OB-1/13, OB-2/13 & $\mathrm{V}-\mathrm{V}$ ' & & Sz438 \\
\hline 14 & OB-1/14 & VI-VI' & & \\
\hline 5 & & VII-VII' & & \\
\hline
\end{tabular}

\section{Szczegółowe wyniki wykonanych badań geologicznych na tle dotychczasowych badań literaturowych}

Obszar badań zlokalizowany jest w obrębie fliszowych Karpat zewnętrznych i charakteryzuje się zróżnicowaną budową geologiczną [9]. Pod względem stratygraficznym wyróżnić można osady kredy, paleogenu oraz czwartorzędu. Przez obszar badań przebiega nasunięcie jednostki magurskiej na jednostkę śląską. Strefa nasunięcia o przebiegu SW-NE jest silnie zaburzona tektonicznie, czego wynikiem jest znaczne osłabienie górotworu. Warstwy są często zbrekcjowane, rozluźnione i wymieszane. Istnienie stref dyslokacyjnych z brekcją tektoniczną sprzyja powstawaniu osuwisk [4], [5]. Oprócz nasunięcia jednostki magurskiej na śląską, występuje na badanym obszarze szereg uskoków poprzecznych, zrzutowo - przesuwczych różnej wielkości i rangi, z których największe to: uskok Mucharza Skawy o przebiegu SE-NW, uskok Zagórza o przebiegu SE-NW, uskok Łękawicy o przebiegu S-N, uskok Stryszówki o przebiegu S-N, uskok Jaszczurowej o przebiegu SENW. Część uskoków może być młodsza od nasunięcia, zatem nie wyklucza się, że niektóre z nich związane są ruchami geotektonicznymi jak np. fragment uskoku Mucharza-Skawy. W budowie jednostki magurskiej (południowa część rejonu badań) dominują piaskowce glaukonitowe warstw magurskich, ciężkowickich i inoceramowych oraz lupki pstre. Jednostkę śląską (północną część rejonu badań) reprezentują warstwy krośnieńskie wykształcone jako piaskowce krośnieńskie oraz łupki krośnieńskie, a także warstwy godulskie górne (piaskowce i łupki ze zlepieńcem malinowskim w stropie), warstwy 
istebniańskie dolne (piaskowce i łupki) oraz warstwy hieroglifowe. Całość terenu pokryta jest glinami i pyłami z rumoszem, których miąższość lokalnie dochodzi do kilku metrów. W dnach dolin występują zróżnicowane litologicznie i miąższościowo osady akumulacji rzecznej wypełniające dolinę rzeki Skawy i jej dopływów. Osady rzeczne wykształcone są w postaci żwirów, pospółek i piasków różnoziarnistych o miąższości najczęściej kilku metrów, pośród których lokalnie występują niewielkiej miąższości wkładki gruntów organicznych (torfy, namuły). Miejscami osady piaszczysto-żwirowe przykryte są warstwą glin o niewielkiej miąższości. Zbocza stoków pokryte są zwietrzeliną utworów fliszowych, w skład której wchodzą pyły, gliny, gliny pylaste i piaszczyste z rumoszem skał podłoża. Miąższość tych utworów nie przekracza kilku metrów. W dolnej partii stoków, na obszarach osuwiskowych, utwory akumulacji rzecznej przykryte są lokalnie koluwiami. Osuwiska rozwinęły się najczęściej w obszarze wychodni warstw inoceramowych, łupków pstrych, warstw magurskich, a w północnozachodniej części terenu na warstwach istebniańskich górnych i dolnych, warstwach krośnieńskich i godulskich. Ruchy grawitacyjne objęły zarówno utwory czwartorzędowe jak i skały podłoża fliszowego. Na omawianym obszarze występują dwa poziomy wodonośne [2], [11]: - czwartorzędowy, obejmującego fragment doliny Skawy, - paleogeńsko - kredowy (fliszowy). Poziom czwartorzędowy występuje w obrębie rzecznych osadów doliny Skawy, wykształconych w postaci otoczaków oraz żwirów i piasków. Zasilanie wód podziemnych poziomu czwartorzędowego odbywa się poprzez bezpośrednią infiltrację opadów atmosferycznych, a także infiltrację wód powierzchniowych. Poziom wodonośny w sąsiedztwie rzeki Skawy uzależniony jest ściśle od jej stanów. Poziom paleogeńsko-kredowy (fliszowy) zbudowany jest $\mathrm{z}$ utworów fliszowych wykształconych w postaci piaskowców przekładanych łupkami ilasto-marglistymi. Poziom wodonośny stanowi strefa przypowierzchniowa spękanych piaskowców zawierających wkładki łupków o miąższości na ogół do $60-80 \mathrm{~m}$. Zasilanie fliszowego poziomu wodonośnego odbywa się $\mathrm{w}$ drodze bezpośredniej infiltracji opadów atmosferycznych na wychodniach spękanych piaskowców, a także poprzez pokrywę zwietrzelinową o miąższości na ogół 1-3 m.

\section{Podsumowanie}

Dla zboczy doliny Skawy w rejonie zapory Świnna Poręba wykonane zostały szczegółowe badania polegające na wykonaniu geologicznych otworów badawczych, inklinometrów, piezometrów, przekrojów geologiczno-inżynierskich, profili sejsmicznych, profili geoelektrycznych. Analiza wyników poszczególnych badań pozwoliły na wyselekcjonowanie stref osuwiskowych zlokalizowanych na zboczach zbiornika retencyjnego Świnna Poręba $\mathrm{w}$ ramach procesu zarządzania ryzykiem. Dla osuwisk, co do których stwierdzono konieczność zabezpieczenia sporządzono projekty budowlane i zabezpieczono jeszcze przed napełnieniem zbiornika. Takie postępowanie jest elementem zarządzania ryzykiem osuwiskowym i bezwzględnie powinno być prowadzone podczas realizacji inwestycji takiej jak budowa zbiornika retencyjnego, jak również w trakcie eksploatacji zbiornika. Działanie takie służą służą zapewnieniu bezpieczeństwa obiektu (zapory) oraz mieszkańców okolicznych miejscowości.

\section{Podziękowania}

Artykuł powstał $\mathrm{w}$ ramach realizacji pisemnego porozumienia o współpracy naukowej pomiędzy AGH, a RZGW w Krakowie.

Artykuł finansowany z badań statutowych 16.16.150.545 


\section{Literatura}

1) Bucała A., 2012, Współczesne zmiany środowiska przyrodniczego dolin potoków Jaszcze i Jamne w Gorcach, Prace Geograficzne I G i P Z P A N, 231, 1 - 146.

2) Chowaniec J., Witek K., 2000 - Mapa hydrogeologiczna Polski w skali 1:50 000, ark. Wadowice (994). CAG. Warszawa.

3) Dynowska I., 1971, Typy reżimów rzecznych w Polsce, Zeszyty Naukowe U J, Prace Geograficzne, 28, 1 - 147.

4) Fischer J., Zagrożenie zbiornika Świnna Poręba osuwiskami, IX Konferencja Sozologiczna PTG, Świnna Poręba 1988, str. 117-132.

5) Gałaś A., Paulo A., 2001 - Osuwiska w otoczeniu zbiornika Świnna Poręba, Przewod.72 Zjazdu PTG, 11-15 września 2001, Kraków, str. 262-266.

6) Gil E., 1986, Rola użytkowania ziemi w przebiegu spływu powierzchniowego $i$ splukiwania na stokach fliszowych, Przegląd Geograficzny, 58, 1 - 2, 51 - 65.

7) Klimek K., 1983, Erozja wgłębna dopływów Wisty na przedpolu Karpat, [ w : ] Z. Kajak ( red. ), Ekologiczne podstawy zagospodarowania Wisty i jej dorzecza, Warszawa - Ł $\square$ ź, $97-108$.

8) Kostrzewski A., Zwoliński Z., 1992, Udziat denudacji chemicznej i mechanicznej we wspótczesnym systemie geomorfologicznym górnej Parsęty ( Pomorze Zachodnie ), [ w : ] A. Kotarba ( red. ), System denudacyjny Polski, Prace Geograficzne IG i P Z P A $\mathrm{N}, 155,11-45$.

9) Książkiewicz M., Szczegółowa mapa geologiczna Polski w skali 1 : 50 000, ark. Sucha Beskidzka. Wyd. Geol. Warszawa 1974.

10) Lach J., 1984, Geomorfologiczne skutki antropopresji rolniczej w wybranych częściach Karpat i ich Pogórza, Prace Monograficzne WSP w Krakowie, 66, 1 - 120.

11) Malinowski J., red., Budowa hydrogeologiczna Polski, Tom VII - Hydrogeologia. Wyd. Geol. Warszawa 1991.

12) Pietrzak M., 2002, Geomorfologiczne skutki zmian użytkowania ziemi na Pogórzu Wiśnickim, Instytut Geografii i Gospodarki Przestrzennej UJ, 1 - 149.

13) Soja R., 2003, Wody, [ w : ] A. Górecki, K. Krzemień, S. Skiba, B. Zemanek ( red. ), Przyroda Magurskiego Parku Narodowego, Oficyna Wydawnicza TEXT, Krak $\square, 43$ $-50$.

14) Święchowicz J., 2002, Współdziałanie procesów stokowych i fluwialnych $w$ odprowadzaniu materiału rozpuszczonego i zawiesiny ze zlewni pogórskiej, Instytut Geografii i Gospodarki Przestrzennej UJ, 1 - 152.

15) Święchowicz J., 2012, Wartości progowe parametrów opadów deszczu inicjujacych procesy erozyjne w zlewni uzytkowanej rolniczo, Instytut Geografii i Gospodarki Przestrzennej UJ, Kraków, 1 - 282.

16) Teisseyre A.K., 1991, Klasyfikacja rzek $w$ świetle analizy systemu fluwialnego $i$ geometrii hydraulicznej, Prace Geologiczno-Mineralogiczne, 22, Wydawnictwo Uniwersytetu Wrocławskiego, Wrocław.

17) Thiel K. i in.: Właściwości fizyko - mechaniczne i modele masywów skalnych polskich Karpat fliszowych, Gdańsk Instytut Budownictwa Wodnego PAN, 1995.

18) Wyżga B., 2003, Współczesne wcinanie się rzek polskich Karpat-przyczyny, przebieg, skutki, [ w : ] J. Lach ( red. ), Dynamika zmian środowiska geograficznego pod wplywem antropopresji, Akademia Pedagogiczna, Kraków, 161 - 167.

19) Zabuski L., Thiel K., Bober L., Osuwiska we fliszu Karpat Polskich. Geologia modelowanie - obliczenia stateczności, Wydawnictwo IBW PAN. Gdańsk 1999.

20) RZGW (2018) Regionalny zarząd Gospodarki Wodnej. Wody Polskie. http://www.krakow.rzgw.gov.pl 
21) KZGW, Plan gospodarowania wodami na obszarze dorzecza Wisły, Warszawa, 2011. 